\title{
Kerentanan Pesisir Selatan KabupatenTulungagung Terhadap Gelombang Tsunami Berbasis Data Spasial
}

\author{
Sonny Robert Dirgantoro' ${ }^{1}$, M. Ruslan², Emmy Sri Mahreda ${ }^{3}$, Kissinger $^{4}$ \\ ${ }^{1}$ Prodi Pengelolaan SumberDaya Alam dan Lingkungan, Fakultas Pertanian, Universitas LambungMangkurat \\ e-mail: robertdirgantoro@gmail.com \\ ${ }^{2}$ Prodi Pengelolaan SumberDayaAlam dan Lingkungan, Fakultas Pertanian, Universitas LambungMangkurat \\ e-mail: ruslanmuhammadmsi@gmail.com \\ ${ }^{3}$ Prodi Pengelolaan Sumber Daya Alam dan Lingkungan, FakultasPertanian, Universitas LambungMangkurat \\ e-mail: mahredaemmy@gmail.com \\ ${ }^{4}$ Prodi Pengelolaan SumberDaya Alam dan Lingkungan, Fakultas Pertanian, Universitas LambungMangkurat \\ e-mail: mrkissingermsi@gmail.com
}

\begin{abstract}
Indonesia is an archipelago that is surrounded by tectonic plates that are active and always experiencing movement. Meanwhile, active and inactive volcanoes are mostly located on the islands of Sumatra and Java. Several earthquakes in Indonesia caused tsunamis, recorded a large earthquake (7.8 Mw) in 1992 in Flores, East Java (7.8 $\mathrm{Mw}$ ) in 1994, in Aceh 2004 (9.0 Mw), Nias (8.7 Mw) in 2005, Pangandaran (7.7 Mw) and Yogyakarta (5.9 Mw) in 2006 followed by a tsunami wave (BMKG Tsunami Catalog, 2018). According to the data, there is not much seismic history in the south of Java Island, compared to the west of Sumatra, Sulawesi and Maluku Islands.

Tulungagung Regency, part of the sub-district which is located in the south is directly adjacent to the open sea, namely the Indian Ocean. It is recorded in history that the southern region of Tulungagung Regency was affected by the tsunami waves caused by the tectonic earthquake in the south of Banyuwangi Regency on June 2, 1994, whose center was at coordinates -10.48 LS and 111.83 East Longitude (usgs.gov). The tsunami waves that hit the southern coast of Tulungagung Regency, in several areas with varying wave heights, recorded the highest waves reaching 4.8 meters on Popoh Beach (usgs.gov). The method used in this study is to use GIS weighted overlay analysis to obtain a tsunami wave vulnerability map by entering parameters that affect the vulnerability of an area to tsunami waves (Diposaptono and Budiman, 2006, in Seandy Firmansyah, IPB, 2012). The weight for each parameter was determined using the Analytical Hierarchy Process (AHP) method.
\end{abstract}

Keywords: tsunami, gis, ahp, tulungagung

\begin{abstract}
ABSTRAK
Indonesia merupakan negara kepulauan yang dikelilingi dengan lempeng tektonik yang aktif dan selalu mengalami pergerakan. Sementara gunung api baik yang aktif maupun yang tidak aktif, sebagian besar terdapat di Pulau Sumatera dan Pulau Jawa. Beberapa kejadian gempa di Indonesia menimbulkan tsunami, tercatat kejadian gempa yang besar (7.8 Mw) tahun 1992 di Flores, Jawa Timur (7.8 Mw) tahun 1994, di Aceh 2004 (9.0 Mw), Nias (8.7 Mw) di tahun 2005, Pangandaran (7.7 Mw) dan Yogyakarta (5.9 Mw) di tahun 2006 diikuti dengan gelombang tsunami (Katalog Tsunami BMKG, 2018). Data tersebut, sejarah kegempaan di sebelah selatan Pulau Jawa tidak begitu banyak, dibandingkan dengan sebelah barat Pulau Sumatera, Sulawesi dan Maluku.

Kabupaten Tulungagung, sebagian wilayah kecamatan yang terletak di sebelah selatanberbatasan langsung dengan laut terbuka, yaitu Samudera Hindia. Tercatat dalam sejarah, bahwa wilayah selatan Kabupaten Tulungagung terdampak oleh gelombang tsunami yang diakibatkan oleh gempa tektonik di selatan Kabupaten Banyuwangi pada tanggal 2 Juni 1994, yang pusatnya berada pada koordinat -10.48 LS dan 111.83 BT (usgs.gov). Gelombang tsunami menerjang pesisir selatan Kabupaten Tulungagung, di beberapa wilayah dengan tinggi gelombang yang variatif, tercatat gelombang tertinggi mencapai 4.8 meter di Pantai Popoh (usgs.gov). Metode yang digunakan dalam penelitian ini adalah memanfaatkan perangkat lunak Sistem Informasi Geografis (SIG) dengan menggunakan metode analisis weighted overlay untuk mendapatkan peta kerentanan gelombang tsunami dengan memasukkan parameter yang mempengaruhi kerentanan suatu wilayah terhadap gelombang tsunami (Diposaptono dan Budiman, 2006, dalam Seandy Firmansyah, IPB, 2012). Bobot untuk masing-masing parameter ditentukan dengan metode Analytical Hierarchy Process (AHP).
\end{abstract}

Kata kunci: tsunami, gis, ahp, tulungagung 


\section{PENDAHULUAN}

Indonesia merupakan negara kepulauan yang beradapada jalur "Cincin Api" atau "Ring ofFire", yaitu terletak pada tiga lempeng tektonik aktif, hal ini sering memicu gempa bumi tektonik dan mengaktifkan gunung berapi yang dapat menyebabkan gempa bumi vulkanis dengan kekuatan yang variatif. Daerah pesisir barat sepanjang Sumatera, pesisir selatan Jawa, Bali, NTB, NTT, merupakan jalur pertemuan antara lempeng India - Australia dan Eurasia. Sedangkan di sebelah utara Sulawesi, kepulauan Maluku, dan pesisir barat Papua merupakan jalur pertemuan lempeng Pasifik dengan lempeng Eurasia. Gempa bumi yang sering terjadi di Indonesia disebabkan oleh kejadian tersebut, yang sebagian berpotensi tsunami dan sebagian yang tidak berpotensi tsunami.

Gempa yang pernah mengguncang di beberapa daerah yang disertai dengan gelombang tsunami di Indonesia, seperti Banyuwangi (1994), Aceh (2004), Pangandaran dan Yogyakarta (2006) tidak terlepas dari sejarah masa lalu yang disebut oleh beberapa peneliti merupakan siklus pengulangan dari gempa terdahulu, meskipun sangat sulit untuk dapat diperkirakan waktu kejadian dan lokasi pusat gempa dapat kembali terjadi pada masa yang akan datang. Lembaga Ilmu Pengetahuan Indonesia (LIPI) meneliti tentang gempa yang diikuti oleh gelombangtsunami yang menerjang Pangandaran (2006) menemukan bahwa pusat gempa(epicentrum) berdekatan dengan pusat gempa yang pernah terjadi pada tanggal11 September 1921 (LIPI, 2009).

Daerah pesisir selatan Jawa Timur, terutama Kabupaten Tulungagung merupakan daerah yang rentan akan dampak tsunami, karena daerah pesisirnya berhadapan langsung dengan Samudera Hindia atau merupakan perairan yang terbuka (open sea). Gempa bumi yang kemudian disusul dengan gelombang tsunami yang pernah menerjang wilayah pesisir selatan Banyuwangi dan Jember dan beberapa kabupaten lainnya di Jawa Timur, pada tanggal 2 Juni 1994 silam menjadikan kewaspadaan untuk wilayah pesisir selatan di Jawa Timur. Epicenter (sumber gempa) dengan kekuatan $7.8 \mathrm{Mw}$ tersebut berada di tenggara, selatan Pulau Jawa terjadi pada pukul 01:17 WIB (Y. Tsuji dkk, 1995).

Getaran yang dihasilkan oleh gempa tersebut tidak begitu terasa oleh masyarakat di sekitar pesisir, demikian juga dengan laporan adanya kerusakan infrastruktur akibat guncangan. Namun sekitar 40-50 menit kemudian gelombang tsunami besar menerjang pantai di pesisir Banyuwangi dan Jember. Berdasarkan penelitian yang pernah dilakukan oleh Matsutomi dkk (1995), masa kisaran tsunami berlangsung sekitar 1015 menit dan gelombang tsunami menerjang pantai 34 kali dan gelombang kedua merupakan gelombang
terbesar.Gelombang tsunami mencapai pesisir selatan Kabupaten Tulungagung, meskipun kerusakan yang ditimbulkan tidak terlalu parah jika dibandingkan dengan Kabupaten Banyuwangi dan Kabupaten Jember, dikarenakan jarak sumber gempa lebih dekat dengan kedua kabupaten tersebut. Sementara itu Badan Penanggulangan Bencana Daerah (BPBD) Kabupaten Tulungagung menyatakan bahwa 3 (tiga) daerah pesisir selatan Tulungagung, yang merupakan kawasan wisata pantai di Kabupaten Tulungagung, yaitu Pantai Sidem Pantai Popoh dan Pantai Sine merupakan daerah yang rawan terhadap gelombang tsunami (BPBD Kabupaten Tulungagung, 2016).

Sebagai upaya untuk mendukung langkah mitigasi bencana tsunami, salah satunya adalah dengan memetakan tingkat kerentanan bencana tsunami dan zona genangan akibat gelombang tsunami, yang nantinya berhubungan dengan jarak aman penduduk dapat menghindari daerah genangan di Kabupaten Tulungagung, terutama di daerah pesisir selatan Kabupaten Tulungagung, yang dapat dijadikan sebagai masukan dan pertimbangan instansi terkait, terutama dalam penyusunan Rencana Tata Ruang Wilayah (RTRW) yang berbasis tingkat risiko bahaya tsunami.

\section{TINJAUAN PUSTAKA}

\section{Tsunami}

Tsunami berasal dari bahasa Jepang yang terdiri dari kata "tsu" yang berarti pelabuhan dan "nami" yang berarti gelombang. Tsunami merupakan gelombang laut yang terjadi karena adanya gangguan impulsif di laut, yang secara ilmiah tsunami dapat didefinisikan sebagai gelombang panjang yang timbul akibat adanya perubahan dasar laut atau perubahan badan air yang terjadi secara tiba-tiba dan impulsif akibat gempa bumi, erupsi vulkanik, longsoran bawah laut atau runtuhan gunung es dan bahkan sebagai akibat dari tumbukan benda-benda angkasa (Latief 2005).Tidak semua gempa menimbulkan dan memicu terjadinya tsunami, ada beberapa criteria gempa yang dapat menimbulkan tsunami. Menurut Sutowijoyo (2005), karakteristik gempa bumi yang dapat menimbulkan tsunami besar antara lain:

1. Gempa bumi terjadi pada sesar naik (thrust/reverse fault), tipe sesar jenis ini sangat efektif dalam memindahkan massa air di atasnya yang merupakan cikal bakal terjadinya tsunami.

2. Kemiringan sudut tegak antar lempeng yang bertemu, semakin besar sudutnya (mendekati $90^{\circ}$ ) maka semakin besar efek tsunami yang terbentuk.

3. Kedalaman pusat gempa yang dangkal $(<70 \mathrm{~km})$.

\section{Karakteristik tsunami}

Karakteristik gelombang tsunami berbeda dengan gelombang air laut biasa atau yang hanya terjadi 
karena pengaruh terpaan angin dan pasang surut dan hanya terjadi di permukaan air saja, sedangkan gelombang tsunami memiliki karakteristik yang lebih unik, karena bentuk gelombangnya memanjang sampai ke seluruh kolom air dari dasar hingga ke permukaan laut (UNESCO-IOC, 2006 dalam Ernawati Sengaji 2009).

Gelombang tsunami di perairan laut dalam, dapat bergerak pada kisaran kecepatan 500 hingga $1.000 \mathrm{~km}$ per jam (sekitar 0,14 - 0,28 kilometer per detik) di perairan terbuka, maka siklus satu gelombang (periode) gelombang dapat mencapai hitungan beberapa menit hingga satu jam. Meskipun demikian, peristiwa tsunami tetap dapat diketahui lebih awal, yakni dengan mendeteksi getaran gempa penyebab tsunami tersebut. Getaran gempa bumi memiliki kecepatan sekitar 4 kilometer per detik (14.400 $\mathrm{km} / \mathrm{jam})$. Hal ini menyebabkan tsunami bisa terdeteksi sebelum mencapai tanah. Mendekati daerah pantai, kecepatan gelombang akan berkurang atau melambat menjadi beberapa puluh kilometer per jam dengan ketinggian gelombang bisa mencapai puluhan meter pada garis pantai. Seperti terlihat pada Gambar 2.1. (UNESCO-IOC, 2006 dalam Ernawati Sengaji 2009).

\section{METODE PENELITIAN}

\section{Lokasi penelitian}

Lokasi penelitian dilakukan di Kabupaten Tulungagung, Provinsi Jawa Timur, secara astronomis terletak pada posisi koordinat 1110 43' - 112007 ' BT 70 51' - 80 18' LS (Gambar 1).

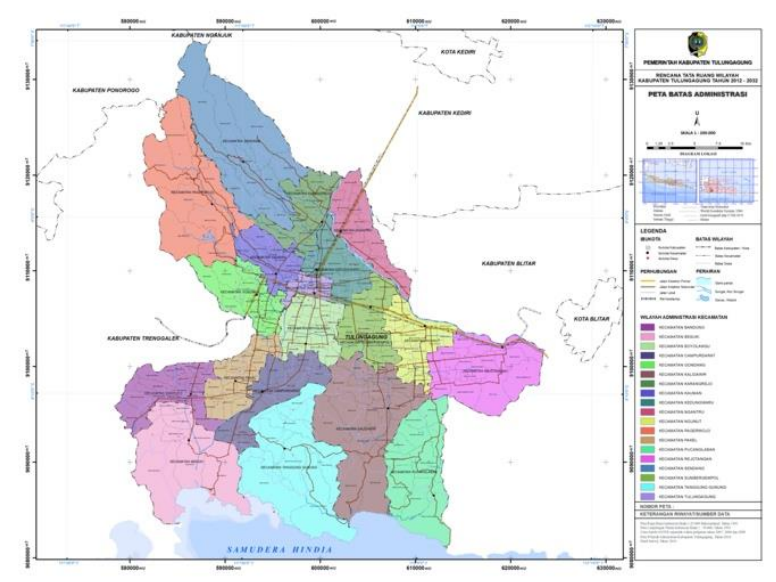

Gambar 1. Lokasi Penelitian

\section{Metodologi}

Penelitian ini dilakukan dengan analisis secara kualitatif dan kuantitatif, yaitu dengan menggunakan data skunder dengan metode pembobotan dan scoring serta tumpang susun (overlay) dengan menggunakan perangkat lunak ArcGIS 10.1 untuk beberapa parameter yang mempengaruhi kerentanan suatu wilayah terhadap gelombang tsunami. Parameter tersebut adalah jarak suatu wilayah dari garis pantai, ketinggiandaratan (elevasi daratan), jarak dari sungai, jarak pantai dari sumber gempa, dan kemiringan lereng. Parameter tersebut diatas dibuat matriks seperti tampak pada Tabel 1 .

Tabel 1. Matriks Parameter Kerentanan Tsunami

\begin{tabular}{lcc}
\hline Parameter & Kriteria & Skor \\
\hline Jarak dari garis pantai & $<500 \mathrm{~m}$ & 0 \\
\hline & $500-1.000 \mathrm{~m}$ & 1 \\
\hline & $1.000-2.000 \mathrm{~m}$ & 2 \\
\hline Ketinggian daratan & $2.000-3.000 \mathrm{~m}$ & 3 \\
\hline & $>3.500 \mathrm{~m}$ & 4 \\
\hline & $0-5 \mathrm{~m}$ & 0 \\
\hline & $5-10 \mathrm{~m}$ & 1 \\
\hline Jarak dari sungai & $10-15 \mathrm{~m}$ & 2 \\
\hline & $15-20 \mathrm{~m}$ & 3 \\
\hline & $20-25 \mathrm{~m}$ & 4 \\
\hline $0-500 \mathrm{~m}$ & 0 \\
\hline Jarak pantai dari sumber & $500-1.000 \mathrm{~m}$ & 1 \\
\hline gempa & $1000-1.500 \mathrm{~m}$ & 2 \\
\hline & $1.500-2.000 \mathrm{~m}$ & 3 \\
\hline$>2.000 \mathrm{~m}$ & 4 \\
\hline & $0-150 \mathrm{~km}$ & 0 \\
\hline & $150-300 \mathrm{~km}$ & 1 \\
\hline Kemiringan lereng & $300-450 \mathrm{~km}$ & 2 \\
\hline & $450-600 \mathrm{~km}$ & 3 \\
\hline$>600 \mathrm{~km}$ & 4 \\
\hline & $0-2 \%($ Datar) & 0 \\
\hline & $2-6 \%(\mathrm{Landai})$ & 1 \\
\hline & $6-13 \%($ AgakCuram$)$ & 2 \\
\hline $13-20 \%(\mathrm{Curam})$ & 3 \\
\hline & $20-55 \%$ (SangatCuram) & 4 \\
\hline
\end{tabular}

Sumber: modifikasi Diposaptono dan Budiman

Zhafran M. Asyam Bustomi

Tabel tersebut di atas, diberikan skala 0-4 menunjukkan tingkat kerentanan terhadap gelombang tsunami (sangat tinggi, tinggi, sedang, rendah dan sangat rendah).

\section{Pengumpulan data}

Data yang digunakan untuk menentukan parameter kerentanan tsunami dengan metodeAnalytical Hierachy Process (AHP), pengambilan keputusannya dilakukan dengan menggunakan persepsi responden dengan cara depth interview dari beberapa ahli di bidangnya. Penyebaran kuisionerdilakukan kepada empat responden dari unsur PVMBG Kementerian ESDM dan BPBD KabupatenTulungagung.

Kemudian data untuk keperluan pengolahan data spasial, diambil dari berbagai sumber, yaitu data peta batas administrasi dan peta kontur dari BAPPEDA Kabupaten Tulungagung, peta historis gempa bumi dari United States Geological Survey (USGS) dari laman usgs.gov dan Global Centroid Moment Tensor (GCMT).

\section{Tahap pembobotan}

Langkah-langkah dalam melakukan pembobotan dalam metode Analytical Hierarchy Process (AHP) adalah sebagai berikut: 
1. Menentukan parameter kriteria yang mempengaruhi kerentanan suatu wilayah terhadap gelombang tsunami dan menyusunnya ke dalam bentuk matriks perbandingan berpasangan (Tabel 2);

2. Menjumlahkan setiap kolom kriteria pada Tabel 2;

3. Menentukan setiap nilai elemen kolom criteria dengan syarat: tiap-tiap sel pada Tabel 2 dibagi dengan masing-masing jumlah kolom pada langkah 2 ;

4. Menentukan peringkat indicator untuk masingmasing baris dalam Tabel 2 dengan persamaan jumlah baris dibagi banyak kriteria;

5. Menguji tingkat konsistensi;

6. Menghitung Lamda $(\lambda)$ dengan persamaan jumlah baris dibagi dengan jumlah prioritas kriteria, Consistency Index (CI) dan Consistency Ratio (CR);dan

7. Menghitung nilai peringkat.

Lebih jelas untuk langkah pembobotan dapat dilihat pada diagram alur (Gambar 2).

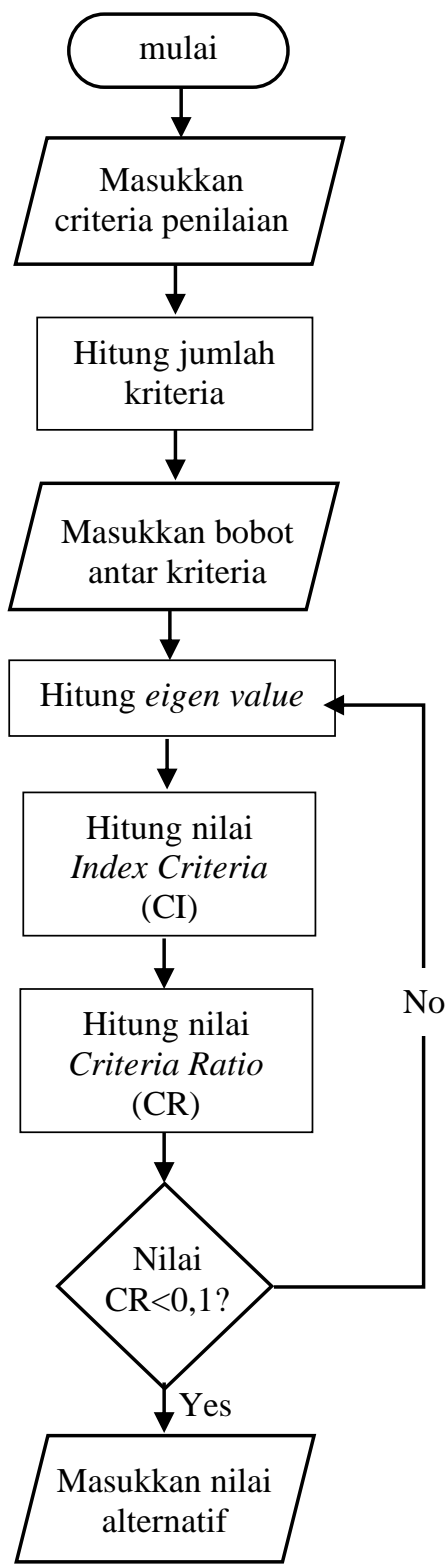

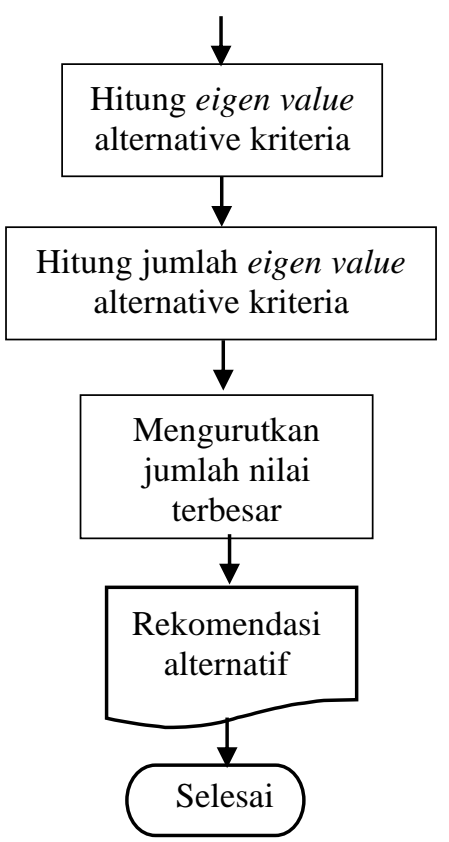

Gambar 2. Diagram Alur Pembobotan Perhitungan bobot parameter

1. Membuat matriks berpasangan dari hasil wawancara dengan responden

Tabel 2. Hasil matriks berpasangan responden

\begin{tabular}{|c|c|c|c|c|c|}
\hline Parameter & A & B & C & D & E \\
\hline A & 1.00 & 2.00 & 2.00 & 2.00 & 4.00 \\
\hline B & 0.50 & 1.00 & 2.00 & 3.00 & 3.00 \\
\hline C & 0.50 & 0.50 & 1.00 & 3.00 & 7.00 \\
\hline D & 0.50 & 0.33 & 0.33 & 1.00 & 7.00 \\
\hline E & 0.25 & 0.33 & 0.14 & 0.14 & 1.00 \\
\hline
\end{tabular}

Keterangan:

$\mathrm{A}=$ Jarak garis pantai

$\mathrm{B}=$ Ketinggian daratan

$\mathrm{C}=$ Jarak dari sungai

$\mathrm{D}=$ Jarak dari sumber gempa

$\mathrm{E}=$ Kemiringan lereng

2. Menghitung eigen value dan menguji nilai konsistensinya

a. Membuat normalisasi matriks kriteria

Tabel 3. Normalisasi matriks kriteria

\begin{tabular}{|l|l|l|l|l|l|}
\hline & \multicolumn{1}{|c|}{$\mathrm{A}$} & \multicolumn{1}{c|}{$\mathrm{B}$} & \multicolumn{1}{c|}{$\mathrm{C}$} & \multicolumn{1}{c|}{$\mathrm{D}$} & $\mathrm{E}$ \\
\hline $\mathrm{A}$ & $1 / 2,75$ & $2 / 4,16$ & $2 / 5,47$ & $2 / 9,14$ & $4 / 22$ \\
\hline $\mathrm{B}$ & $0,5 / 2,75$ & $1 / 4,16$ & $2 / 5,47$ & $3 / 9,14$ & $3 / 22$ \\
\hline $\mathrm{C}$ & $0,5 / 2,75$ & $0,5 / 4,16$ & $1 / 5,47$ & $3 / 9,14$ & $7 / 22$ \\
\hline $\mathrm{D}$ & $0,5 / 2,75$ & $0,33 / 4,16$ & $0,33 / 5,47$ & $1 / 9,14$ & $7 / 22$ \\
\hline $\mathrm{E}$ & $0,25 / 2,75$ & $0,33 / 4,16$ & $0,14 / 5,477$ & $0,14 / 9,14$ & $1 / 22$ \\
\hline
\end{tabular}


b. Menghitung nilai rata-rata setiap baris/bobot prioritas

Tabel 4. Nilai bobot prioritas

\begin{tabular}{|c|c|c|c|c|c|}
\hline Parameter & A & B & C & D & E \\
\hline A & 0,3636 & 0,4808 & 0,3656 & 0,2188 & 0,1818 \\
\hline B & 0,1818 & 0,2404 & 0,3656 & 0,3282 & 0,1364 \\
\hline C & 0,1818 & 0,1202 & 0,1828 & 0,3282 & 0,3182 \\
\hline D & 0,1818 & 0,0793 & 0,0603 & 0,1094 & 0,3182 \\
\hline E & 0,0909 & 0,0793 & 0,0256 & 0,0153 & 0,0455 \\
\hline Jumlah & 1 & 1 & 1 & 1 & 1 \\
\hline
\end{tabular}

c. Menghitung matriks perbandingan dikalikan dengan matriks bobot prioritas

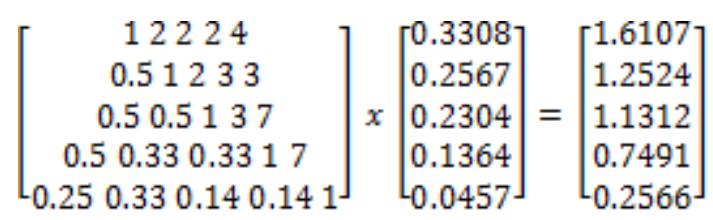

d. Menghitung nilai eigen maksimum (Xmax) dengan cara membagi jumlah tiap baris tiap parameter dengan bobot sintesa, didapatkan hasil seperti pada Tabel 5.

\begin{tabular}{|c|c|c|c|c|c|c|}
\hline $\mathrm{A}$ & $\mathrm{B}$ & $\mathrm{C}$ & $\mathrm{D}$ & $\mathrm{E}$ & $\begin{array}{c}\text { BobotSintes } \\
\mathrm{a}\end{array}$ & $\mathrm{X}$ Max \\
\hline 0,363 & 0,480 & 0,365 & 0,218 & 0,181 & 1,610 & 4,869 \\
\hline 0,181 & 0,240 & 0,365 & 0,328 & 0,136 & 1,252 & 4,879 \\
\hline 0,181 & 0,120 & 0,182 & 0,328 & 0,318 & 1,131 & 4,909 \\
\hline 0,181 & 0,079 & 0,060 & 0,109 & 0,318 & 0,749 & 5,492 \\
\hline 0,090 & 0,079 & 0,025 & 0,015 & 0,045 & 0,256 & 5,610 \\
\hline
\end{tabular}

e. Menghitung nilai $\lambda \max$

Menghitung dengan cara membagi jumlah Xmax dengan jumlah parameter dengan persamaan:

$\lambda$ maks $=\frac{25,761}{5}$

$$
\lambda m a k s=\frac{X m a x}{n}
$$

\section{$\lambda$ maks $=5,152$}

f. Menghitung nilai konsistensi

Jumlah parameter $(\mathrm{n})=5$

Indeks rasio $(R I)=1,11$

Konsistensi Index (CI)

$C I=\frac{\lambda \text { maks }-n}{n}$

$C I=\frac{5,152^{n}-5}{5}$

$C I=0,0304$

Konsistensi Ratio (CR)

$$
\begin{aligned}
C R & =\frac{C I}{R I} \\
C R & =\frac{0,0304}{1,11} \\
C R & =0,0274
\end{aligned}
$$

Dari hasil perhitungan di atas didapat bahwa nilai konsistensi berada di bawah 0,1 yang berarti bahwa hasilnya konsisten atau memenuhi syarat.

\section{Overlay parameter}

Hasil dari perhitungan AHP tersebut, seluruh bobot dikalikan dengan skor untuk setiap parameter, dan

\begin{tabular}{|c|c|c|c|c|}
\hline Parameter & Kriteria & Skor & Bobot & Nilai \\
\hline \multirow[t]{5}{*}{$\begin{array}{l}\text { Jarak dari } \\
\text { garis pantai } \\
\end{array}$} & $<500 \mathrm{~m}$ & 0 & \multirow{5}{*}{0,330} & 0 \\
\hline & $500-1.000 \mathrm{~m}$ & 1 & & 0,330 \\
\hline & $\begin{array}{c}1.000-2.000 \\
\mathrm{~m}\end{array}$ & 2 & & 0,660 \\
\hline & $\begin{array}{c}2.000-3.000 \\
\mathrm{~m} \\
\end{array}$ & 3 & & 0,990 \\
\hline & $>3.500 \mathrm{~m}$ & 4 & & 1,323 \\
\hline \multirow[t]{5}{*}{$\begin{array}{l}\text { Ketinggiandara } \\
\text { tan } \\
\end{array}$} & $0-5 \mathrm{~m}$ & 0 & \multirow{5}{*}{0,256} & 0 \\
\hline & $5-10 \mathrm{~m}$ & 1 & & 0,256 \\
\hline & $10-15 \mathrm{~m}$ & 2 & & 0,513 \\
\hline & $15-20 \mathrm{~m}$ & 3 & & 0,770 \\
\hline & $20-25 \mathrm{~m}$ & 4 & & 1,026 \\
\hline \multirow[t]{5}{*}{\begin{tabular}{|l|l} 
Jarak \\
darisungai
\end{tabular}} & $0-500 \mathrm{~m}$ & 0 & \multirow{5}{*}{0,136} & 0 \\
\hline & $500-1.000 \mathrm{~m}$ & 1 & & 0,136 \\
\hline & $1000-1.500 \mathrm{~m}$ & 2 & & 0,272 \\
\hline & $1.500-2.000 \mathrm{~m}$ & 3 & & 0,409 \\
\hline & $>2.000 \mathrm{~m}$ & 4 & & 0,545 \\
\hline \multirow{5}{*}{$\begin{array}{l}\text { Jarak } \\
\text { pantaidarisum } \\
\text { bergempa }\end{array}$} & $0-150 \mathrm{~km}$ & 0 & \multirow{5}{*}{0,045} & 0 \\
\hline & $150-300 \mathrm{~km}$ & 1 & & 0,045 \\
\hline & $300-450 \mathrm{~km}$ & 2 & & 0,091 \\
\hline & $450-600 \mathrm{~km}$ & 3 & & 0,137 \\
\hline & $>600 \mathrm{~km}$ & 4 & & 0,182 \\
\hline \multirow{6}{*}{$\begin{array}{l}\text { Kemiringanler } \\
\text { eng }\end{array}$} & 0-2\% (Datar) & 0 & \multirow{6}{*}{0,212} & 0 \\
\hline & 2-6\% (Landai) & 1 & & 0,212 \\
\hline & 6-13\% (Agak & 2 & & 0,425 \\
\hline & Curam) & & & \\
\hline & $\begin{array}{l}13-20 \% \\
\text { (Curam) } \\
\end{array}$ & 3 & & 0,637 \\
\hline & $\begin{array}{c}20-55 \% \\
\text { (SangatCuram) }\end{array}$ & 4 & & 0,850 \\
\hline
\end{tabular}
dikonversikan ke dalam basis data SIG untuk diberikan nilai melalui table matematika (Tabel 5).

Tabel 5. Bobot dan skor parameter tsunami

Sumber: Hasil analisis

Dari tabel di atas, penulis menggunakan asumsi bahwa skor 0 memiliki kerentanan yang tinggi, karena berbanding lurus dengan tingkat keselamatan yang rendah, sebaliknya skor 4 memiliki tingkat kerentanan yang rendah, karena tingkat keselamatan yang tinggi. Sehingga dari tabel di atas dituangkan dalam bentuk Tabel 6 . 
Tabel 6. Nilai total parameter

\begin{tabular}{lc}
\hline \multicolumn{1}{c}{ Parameter } & Nilai Total \\
\hline Jarak dari garis pantai & $\mathbf{3 , 3 0 3}$ \\
\hline Ketinggian daratan & $\mathbf{2 , 5 6 5}$ \\
\hline Kemiringan lereng & $\mathbf{2 , 1 2 4}$ \\
\hline Jarak dari sungai & $\mathbf{1 , 3 6 2}$ \\
\hline Jarak pantai dari sumber gempa & $\mathbf{0 , 4 5 5}$ \\
\hline \multicolumn{1}{c}{ Nilai Total } & $\mathbf{9 , 8 0 9}$ \\
\hline
\end{tabular}

Tabel 6 di atas, nilai total adalah 9,809 dan $\mathrm{N}$ berjumlah 5, maka kelas intervalnya adalah:

$L=\frac{\Sigma\left(B_{i} x S_{i}\right) \max -\Sigma\left(B_{i} x S_{i}\right) \min }{n}$

dimana :

$\mathrm{L} \quad=$ lebar interval

$\mathrm{N} \quad=$ jumlah parameter

Maka:

$L=\frac{3,303-0,455}{5}$

$L=\frac{3,303-0,455}{5}$

$L=\frac{2,848}{5}$

$L=3,212$

Lebar interval kelas adalah 3,212, maka hasil tingkat kerentanan seperti pada Tabel 7.

Tabel 7. Interval kelastingkatkerentanan

\begin{tabular}{cc}
\hline Sangat tinggi & $0,455-3,667$ \\
\hline Tinggi & $3,667-6,879$ \\
\hline Sedang & $6,879-10,091$ \\
\hline Rendah & $10,091-13,303$ \\
\hline Sangat rendah & $13,303-16,515$ \\
\hline
\end{tabular}

\section{HASIL DAN PEMBAHASAN}

\section{Jarak dari garis pantai}

Secara umum, semakin dekat suatu wilayah dengan garis pantai, maka memiliki tingkat kerentanan terhadap gelombang tsunami semakin tinggi, dan risiko semakin besar. Sebaliknya semakin jauh suatu wilayah dengan garis pantai, maka tingkat kerentanan terhadap gelombang tsunami semakin rendah dan risiko semakin kecil.
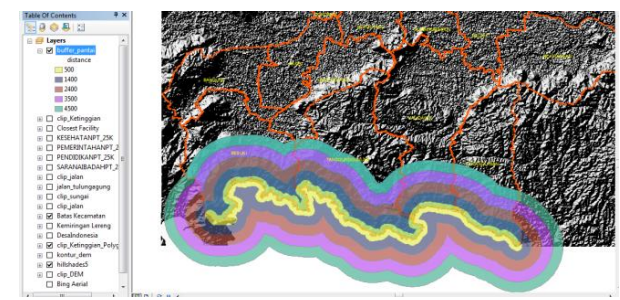

Gambar 3. Jarak wilayah dengan garis pantai Gambar 3. di atas menunjukkan kelas jarak suatu wilayah terhadap garis pantai, dimana jarak 500 meter (warna hijau) dari garis pantai menunjukkan kelas kerentanan yang sangat tinggi dan jarak 4500 meter (warna biru) menunjukkan kelas sangat rendah.

\section{Ketinggian daratan}

Ketinggian daratan suatu wilayah merupakan salah satu parameter kerentanan terhadap gelombang tsunami. Semakin tinggi letak suatu wilayah, tingkat kerentanan terhadap gelombang tsunami semakin rendah dan risiko semakin kecil, sebaliknya semakin rendah letak suatu wilayah, maka tingkat kerentanan terhadap gelombang tsunami semakin besar dan memiliki risiko yang tinggi.

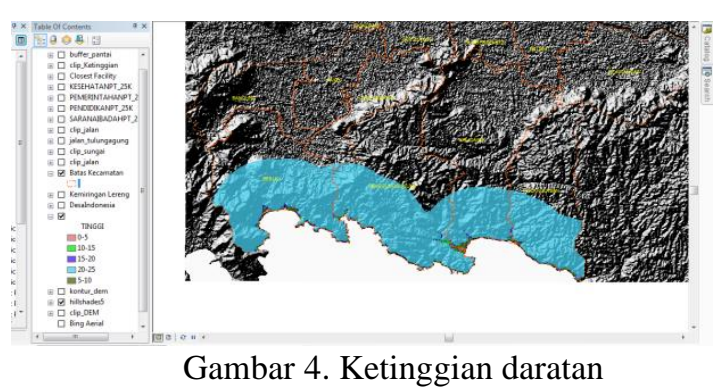

Gambar 4 di atas menunjukkan bahwa di Kabupaten Tulungagung sebagian besar ke arah utara didominasi oleh kelas ketinggian 20-25 meter, hanya sebagaian kecil yang memiliki ketinggian 0-5 meter dan 5-10 meter,yaitu terletak di dekat pantai.

\section{Jarak dari sungai}

Suatu wilayah yang berdekatan dengan sungai merupakan salah satu parameter yang rentan terhadap gelombang tsunami. Hal ini disebabkan karena gelombang tsunami yang berasal dari laut lepas akan memasuki kanal-kanal atau sungai dan menggenangi wilayah daratan melalui muara sungai jika badan sungai tidak lagi mampu menampung air.

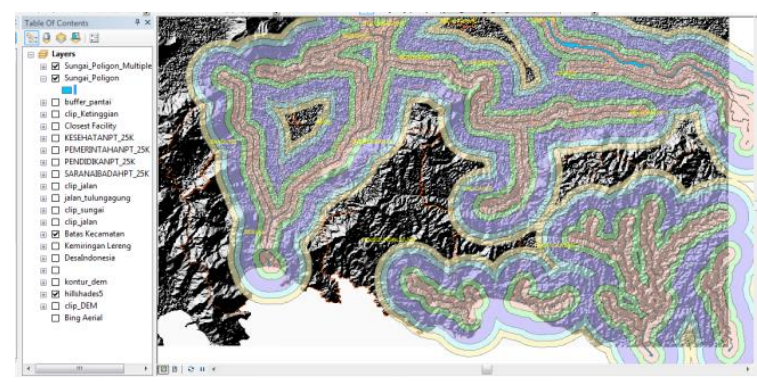

Gambar 5. Jarak dari sungai

Gambar 5 di atas menunjukkan bahwa wilayah yang berdekatan dengan sungai yang bermuara di laut memiliki kelas kerentanan yang tinggi, karena gelombang laut tsunami akan masuk melalui badan sungai dan wilayah tersebut akan tergenang dan menghancurkan sarana prasarana yang berada di dekatnya, tergantung dari kekuatan gelombang tsunami pada saat mencapai daratan. 


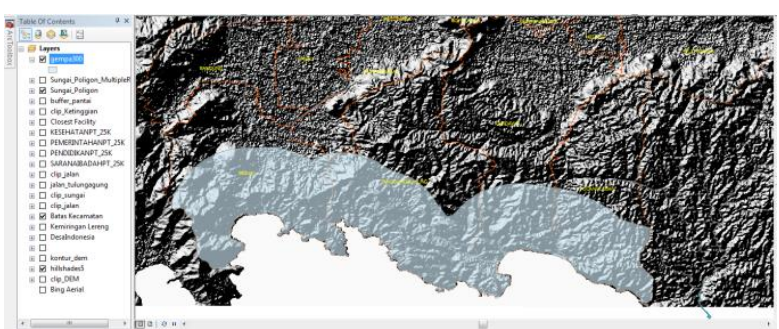

Gambar 6. Jarak dari sumber gempa

\section{Jarak dari sumber gempa}

Jarak suatu wilayah dari sumber gempa juga menentukan tingkat kerentanan dan risikonya, semakin dekat suatu wilayah dengan sumber gempa akan semakin tinggi kelas kerentanannya dan semakin besar risikonya.

Gambar 6 tersebut menunjukkan wilayah di selatan pantai memiliki jarak dari sumber gempa sejauh 3 kilometer, yang sumber gempanya berada di dasar laut di sisi selatan Kabupaten Tulungagung.

\section{Kemiringan lereng}

Gambar 6. Jarak dari sumber gempa

Parameter kemiringan lereng suatu wilayah menentukan tingkat kerentanannya terhadap gelombang tsunami, semakin landai suatu wilayah,memiliki kerentanan yang tinggi terhadap gelombang tsunami, sebaliknya suatu wilayah yang memiliki tingkat kelerengan yang curam akan semakin rendah tingkat kerentannya dan memiliki risiko yang kecil terhadap gelombang tsunami.

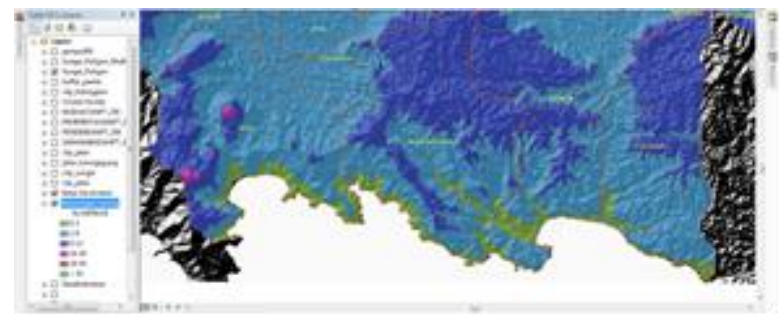

Gambar 7. Kemiringan lereng

Gambar 7 di atas menunjukkan bahwa kemiringan lereng di Kabupaten Tulungagung bervariasi,hanya sebagian kecil saja yang memiliki kelas kelerengan 0 $2 \%$ (datar), selebihnya, ke arah utara memiliki kelas kelerengan 2-6\% (landai) hingga 6-13\% (agak curam).

\section{Analisis tumpang susun (overlay)}

Overlay merupakan analisis yang dilakukan di dalam perangkat lunak ArcGIS dengan menggabungkan beberapa peta (layer) menjadi sebuah peta baru (new layer). Beberapa peta tersebut di atas,yang merupakan beberapa parameter yang mempengaruhi suatu wilayah rentan terhadap gelombang tsunami dilakukan proses tumpang susun sehingga dihasilkan seperti pada Gambar 8.

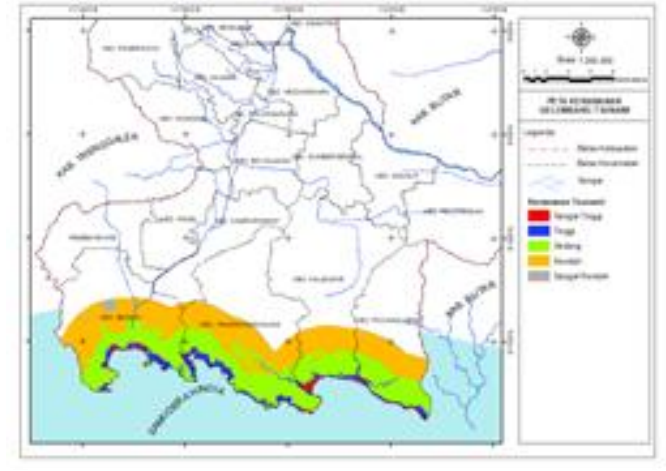

Gambar 8. Peta Kerentanan gelombang tsunami Kabupaten Tulungagung

Gambar 8 tersebut diatas menunjukkan bahwa semakin ke arah utara (menjauhi pantai) memiliki kelas kerentanan rendah. Hasil yang didapat dari hasil overlay tersebut didapatkan hasil sesuai dalamTabel 8 .

\begin{tabular}{lrrrrr}
\multirow{2}{*}{ Kecamatan } & \multicolumn{5}{c}{$\begin{array}{c}\text { Luas Kelas Kerentanan } \\
\text { (Ha) }\end{array}$} \\
\cline { 2 - 6 } & ST & \multicolumn{5}{c}{ T } & S & R & SR \\
\hline Besuki & 99,74 & 422,57 & 2269,01 & 2962,65 & 132,98 \\
\hline Kalidawir & 97,14 & 108,58 & 1128,01 & 1183,60 & 0 \\
\hline Pucanglaban & 59,27 & 146,97 & 1529,89 & 1441,16 & 0 \\
\hline Tanggunggunung & 101,86 & 449,33 & 2776,71 & 2770,39 & 3,63 \\
\hline Keterangan: & & & \\
ST $\quad$ = Sangat Tinggi \\
T $\quad$ Tinggi \\
S $\quad$ Sedang \\
R $\quad$ Rendah \\
SR Sangat Rendah
\end{tabular}

Tabel 8 di atas, di Kecamatan Besuki dan Tanggunggunung terdapat suatu wilayah yang memiliki kelas kerentanan sangat rendah, hal ini dikarenakan pada wilayah tersebut memiliki kelas ketinggian 20-25 meter, yang merupakan sebuah bukit, sehingga memiliki kelas kerentanan sangat rendah.

\section{KESIMPULAN}

\section{Kesimpulan}

Berdasarkan hasil penelitian ini, dapat disimpulkan bahwa:

1. Pembobotan dengan menggunakan Analytical Hierarchy Process (AHP) diperoleh hasil bahwa parameter yang dominan menurut responden adalah jarak suatu wilayah dengan garis pantai dengan nilai bobot tertinggi 3,303 disusul berturut-turut ketinggian daratan $(2,565)$, kemiringan lereng $(2,124)$, jarak dari sungai $(1,363)$ dan terakhir adalah jarak pantai dari sumber gempa $(0,455)$.

2. Berdasarkan analisis spasial, tingkat kerentanan di pesisir selatan Kabupaten Tulungagung diperoleh hasil bahwa kelas kerentanan sangat tinggi terhadap gelombang tsunami adalah Kecamatan Tanggunggunung dengan luas 101,862 hektar, Kecamatan Besuki 99,749 
hektar, disusul kemudian Kecamatan Kalidawir 97,145 hektar dan wilayah terkecil adalah Kecamatan Pucanglaban 59,276 hektar.

\section{Saran}

Dari hasil penelitian ini saran yang dapat diberikan antara lain adalah:

1. Metode pembobotan dengan Analytical Hierarchy Process (AHP) dapat dilakukan untuk pengambilan keputusan yang bersifat kompleks yang merupakan subyektifitas dari para responden. Alternatif dengan menggunakan metode yang lain dapat digunakan untuk mendapatkan hasilyang lebih baik (misal: skala Linkert, dll).

2. Peneliti selanjutnya diharapkan membuat model dengan menggunakan lebih banyak variasi data, sehingga model dapat lebih baik dan detail mendekati kejadian bencana sesungguhnya.

\section{DAFTAR PUSTAKA}

Naryanto, HS, Wisyanto (2005). Kajian dan Analisis Potensi Bencana Tsunami, Konfigurasi Pantai Serta Mitigasi Bencana di Pantai Selatan Jawa Timur: Belajar dari Pengalaman Bencana Tsunami Banyuwangi 1994, Jurnal Alami Vol. 10 No. 2/2005.

Oktariadi, O (2009). Penentuan Peringkat Bahaya Tsunami dengan Metode Analytical Hierarchy Process (Studi kasus: Wilayah Pesisir Kabupaten Sukabumi), Jurnal Geologi Indonesia Vol: 4, No.2 Juni 2009: hal 103 - 116.

Sengaji, E (2009). Pemetaan Tingkat Risiko Tsunami di Kabupaten Sikka, Nusa Tenggara Timur. Jurusan Ilmu dan Teknologi Kelautan, Skripsi.

Oktiari, D, Manurung, S (2010). Model Geospasial Potensi Kerentanan Tsunami Kota Padang, Jurnal Meteorologi dan Geofisika Vol. 11 No. 2/11/2010: hal 140-146.

Surmayadi, Mamay, dkk. (2012). Evaluasi Resiko Bencana Tsunami Kabupaten Banyuwangi Provinsi Jawa Timur. Bandung: Pusat Vulkanologi dan Bencana Geologi.

Faiqoh Iqoh, dkk. (2013). Vulnerability Level Map of Tsunami Disaster in Pangandaran Beach, West Java. International Journal of Remote Sensing and Earth Sciences Vol.10 No. 2/2013: https://www.researchgate.net/publication/ 273451403.

Mardiyanto, B, dkk. (2013). Kajian Kerentanan Tsunami Menggunakan SistemInformasi
Geografi di Kabupaten Bantul, Daerah Istimewa Yogyakarta, Journal of Marine Research Vol. 2 No. 1/2013:hal 103-111.

Islam, F, Subiyanto, S, Sabri, L.M (2014). Penentuan Risiko dan Kerentanan Tsunami di Kebumen dengan Citra Alos, Jurnal Geodesi Undip Vol. 3 No. 1/2014 (ISSN:2337-845X).

Amri, R.M. at al. (2016). Risiko Bencana Indonesia (RBI).BNPB Jakarta.

Sawitri, F, dan Sarno, R. (2016). Prosiding Seminar Nasional Manajemen Teknologi XXV, Program Studi MMT-ITS Surabaya, 30 Juli 2016, ISBN 978-602-70604-4-9. 